\title{
Social evolution in times of COVID-19 between politics, economics, and health
}

\author{
Alessandro Figus \\ University of Cassino and Southern Lazio, Italy
}

\begin{abstract}
As well as highlighting difficulties in the health sector at local, national, and international levels, the COVID-19 pandemic has placed states in crisis by questioning the model of globalization, the political system, and the economic system. The article starts from a historical and philosophical analysis and tries to find solutions for getting out of the crisis. Science alone is not enough; it is necessary to redesign sustainable models in the economy and new political strategies.
\end{abstract}

\section{Keywords}

Social evolution, COVID-19, pandemics, politics, philosophy, economics

\section{Introduction}

The coronavirus pandemic seems to have brought philosophical discussions to every household in the world. The classical themes of philosophy, such as death, freedom, fear, care, love, education, leisure, work, forms of political control, the problem of truth, or the place of science in society, have today become a matter of confrontation and discussion. To this is added the economic problem, in a world already in economic crisis, due to the slowdown of the capitalist system that has governed society in the last century.

The global pandemic has brought millions of people into quarantine. The huge number of deaths has put the system in crisis, the problem of COVID-19 has become global, entering our homes overwhelmingly (Figus, 2020). There is nothing more instructive than silence about the problems. This is why we wonder what philosophy serves in a pandemic. The very idea of utility also becomes a philosophical problem.

Philosophy is defined by the critical claim to address the most important issues and help a closer to the best, recognizing that we start from a state of ignorance that forces us to assiduously question our ideas. After all, philosophy resembles a bit like pandemics, as it pushes us to identify priorities and become aware of our limits, highlighting new problems, it forces us to reflect, much more than political science and economics (Chauncey Crandall M.D., 2020). It is precisely the pandemic that has brought to light our fragility, the fragility of our time, it has brought us back to the raw reality, putting life and the importance of it at the centre. Health has so suddenly become central, a daily discussion in our global communication. Think, for example, of the American presidential elections, their media strength, and yet even these have ended up in the background compared to the pandemic crisis.

Philosophers, who live in a perpetual state of exception, have rediscovered how strategic their role can become in times of crisis, precisely because the philosopher always questions everything. The coining of the word epidemic, Hippocrates, used this term referring to the diseases of distinctive peoples (Angeletti \& Gazzaniga, 2008). The doctor assists the traveller 
who is travelling down a difficult path get closer to his destination, trying to help him as much as possible. Yes, philosophy and pandemic teach something. We are all passing through it and the crisis (another Hippocratic concept) leads to two possible outcomes: relapse or cure. After all, even in this globalized society, there is not much distance between learning to die and learning to live.

Some wanted to tackle this pandemic from a unique perspective. They are wondering how philosophers can contribute; after all, they are a caste of specialists in everything, and, therefore, how is it possible that they can also cure diseases. Topics like what is at stake is our way of life, the society we would like to have, the way we have to educate ourselves and others, do not seem to have been talked about enough in these years, and this is why philosophy comes into play.

The crisis highlights the problems and the crisis has made everyone understand that a society that relies only on the economy does not resist the psychological impact, yet the pandemic is a natural course of things, with its small and rare damages, to bear with patience. We can say that a simple virus cannot move more ideas than a treatise on philosophy.

Hippocrates recommended the doctor to describe the past, know the present and predict the future, listing the things a doctor needs to know to understand his patients, in what is an obvious example of the confluence of philosophy and medicine (Lopez, 2020). The doctor had to learn from nature what is common to all and the peculiar nature of each one, but also from the celestial phenomena and every region, from every place, from the customs of the people, from the diet, from the way of life, from the age of each one, with words, with attitude, with silence, with thought (Angeletti \& Gazzaniga, 2008).

\section{The pandemic today between economy and politics}

Today we rely only on science; in the past, we listened to philosophers more than we do today. The pandemic reminds us of the interconnection of medicine with other realities, where multiple disciplines converge. Today this tends to be forgotten by placing, for example, virology, epidemiology or medicine into the centre of the world. All these indeed have various functions whose articulation depends on factors external to each of them, but they cannot be the driving force of society.
The solution to an epidemic is not limited to the treatment of bodies or the manipulation of viruses in laboratories but implies learning to live with them and prevent them through various measures, including politics, economy and new educational systems.

The first global pandemic in history highlighted contradictions between economy and medicine, between freedom and state control, between telling the truth and avoiding alarmism, between defending our right to demonstrate and limiting contagion. What must prevail? Medicine or economy, politics, religion, or is public health, the protection of people's health the most important issue?

In this context, the essential role is played by the media, which have been prone to one or the other thing, with changing criteria, revealing clear contradictions between medicine and information, between reality and storytelling.

Many see the pandemic as an opportunity for change, an advantage that will help us understand our vulnerability, make us aware of our mutual interdependence, teach us that we are all equal, encouraging us to build a more just society. Some argue that this crisis favours the idea of a more just world. Furthermore, it highlights how this is homologated, flat. It is true, it tends to guarantee human rights, the sustainability of future natural resources, even if more in theory than in practice. We think about climate change and the shared need to take effective measures altogether, but the reality is that you never manage to implement a project to the end, In the end, it seems that globalization has accentuated hypocrisy and not science.

This seems to revive the debate between optimists and pessimists that have emerged in other catastrophes that seem new but in reality, are repeated periodically and are part of our history. Think of the plague in Milan or the Spanish flu of 1918 (Treccani Dictionary, 2020), which caused millions of deaths. History often repeats itself, even the measures to contain the pandemic of a century ago during the Spanish pandemic, seem not many different from today: disinfection and closure of public spaces, theatres, schools, and borders. Since there were no private telephones back then, telephones and even telephone operators were disinfected, where citizens went to make calls. Historians have also discovered that in the United States the fines for those who did not wear a mask amounted to 100 dollars (Kelly, 2020). 
However that was the past; today we are in a globalized world with a globalized economy, and yet suddenly the problem of investment in health and the precariousness of research becomes pressing. Our new goal is no longer economic, but health care. We attach incredible importance to vaccines, changing our idea of the welfare state. We are willing to question our idea of democracy as the sovereignty of the people, especially if we accept the definition of sovereignty as the ability to make decisions in states of emergency.

\section{A historical perspective}

Throughout the history of which there are records, there have been major and relevant pandemics that caused a lot of deaths.

Table 1 Chronology of relevant pandemics, $168-2010$

\begin{tabular}{l|c|c|c}
\hline \multicolumn{1}{c|}{$\begin{array}{c}\text { Historical } \\
\text { Relevant Pandemia }\end{array}$} & from & to & $\begin{array}{c}\text { Death toll } \\
\text { estimated }\end{array}$ \\
\hline $\begin{array}{l}\text { The Antonine Plague (Roman } \\
\text { Empire) }\end{array}$ & $\begin{array}{c}\text { around } \\
168\end{array}$ & 190 & $5-10.000 .000$ \\
\hline $\begin{array}{l}\text { The Japanese smallpox } \\
\text { epidemic }\end{array}$ & 735 & 737 & 2.000 .000 \\
\hline $\begin{array}{l}\text { Black Deaths } \\
\text { The Mexico Smallpox epidemic }\end{array}$ & 1331 & 1353 & 75.000 .00 \\
\hline The Mexico Cocolitzli & 1545 & 1520 & $5-8.000 .000$ \\
\hline The Egyptian Plague & 1609 & 1610 & $\begin{array}{c}10- \\
15.000 .000\end{array}$ \\
\hline The Italian Plague & 1629 & 1632 & 1.000 .000 \\
\hline The Great Plague of Seville & 1647 & 1652 & 2.000 .000 \\
\hline The Great Plague of London & 1665 & 1666 & 100.000 \\
\hline The Great Plague of Marseille & 1720 & 1722 & 100.000 \\
\hline The first Cholera pandemic & 1816 & 1826 & 100.000 \\
\hline The second Cholera pandemic & 1829 & 1851 & 100.000 \\
\hline The Russian Pandemic & 1846 & 1860 & 1.000 .000 \\
\hline The Global flu pandemic & 1889 & 1890 & 1.000 .000 \\
\hline The sixth Cholera Pandemic & 1899 & 1923 & 1.500 .000 \\
\hline Cholera pandemic encephalitic \\
lethargica & 1915 & 1926 & 1.500 .000 \\
\hline The Spanish Flu & 1918 & 1920 & $50-$ \\
\hline The Russian Typhus & 1918 & 1922 & 2.500 .000 \\
\hline The Asian Flu & 1957 & 1958 & 2.000 .000 \\
\hline The Hong Kong Flu & 1968 & 1969 & 1.000 .000 \\
\hline H1N1 pandemic - Swine flu & 2009 & 2010 & 280.000 \\
\hline
\end{tabular}

Source: The author's elaboration based on LePan (2020)

The economy, politics, information, and medicine collide, and this becomes inevitable and unsustainable. These perform different, often contradictory functions. There is no preset harmony or easy solution. There is therefore no shared and homologated philosophy; the crisis has changed the rules and the way the public opinion thinks, but will this last as long as the pandemic and everything will return as before, or has everything changed? Are we tied only to evil materialism or will the power of ideas return to dominate and advance the system?
Perhaps politics will draw great benefits from this experience, medicine will rediscover its role and the economy will take advantage to relaunch itself after the pandemic. In the end, it is the responsibility that must prevail. Meanwhile, the new generations are facing unemployment, but some see in the post-pandemic period the possibility of a revival.

The World Health Organization was as incapable of predicting this pandemic as economists were in the face of the 2008 crisis, which then included institutions such as the World Bank or the International Monetary Fund (United Nations, 2020). The graph shows the "global GDP Growth" over the period 1995-2020, highlights the global crisis of 2008 and the current crisis of 2020 , the only difference that the latter is right outside the economy and is due to the Covid-19 pandemic.

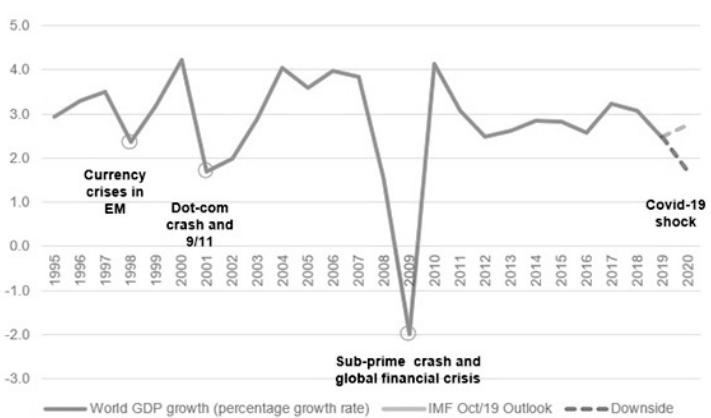

Figure 1 Global GDP Growth, 1995-2020

Source: Calculation based on United Nations Conference on Trade and Development, 2020

The graph below shows how much relationship there is between COVID-19 and the economy, between the pandemic and the economy. It was so for the Spanish pandemic of the last century, it is also so today.

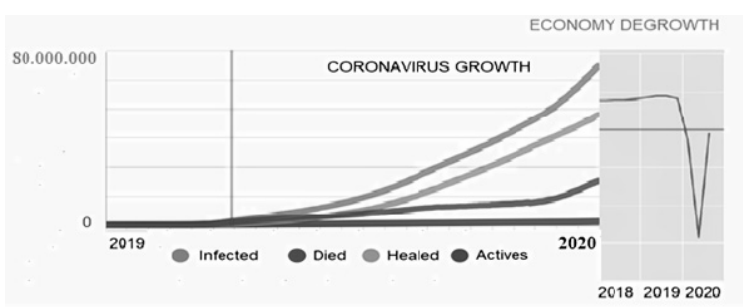

Figure 2 Corona virus Growth's impact on Economic growth

Source: The author elaboration data from World Health Organization, 2020

It is possible to talk about the political economy because, after all, politics affects the economy and the economy affects politics. It is not an economic matter; I am not an economist, 
but I am interested in economics and its interaction with politics, even in the time of COVID-19, this question is not only of an academic nature. I have the impression that we will witness the tragic evolution of the political economy in real-time. The pandemic has led, is leading, and will lead to a terrible loss of life and at the same time the engine of the economy, especially today that we are in a globalized world, is freezing the gears of trade.

People's lives have been deeply shattered and affected by a crisis that is causing widespread unemployment, and while this crisis focuses on health by directing our attention, issues of political economy are more relevant than ever. Thus they underline that policies are not only influenced by economic analysis but also by noneconomic, social, and political forces. Moreover, it forces us to think about how people and the economy will adapt in the post-pandemic, or rather a post-crisis world. The centrality of institutions, looking for sustainable economic policy solutions, is of fundamental importance, as this crisis deprives millions of migrants of job opportunities, reducing remittances, the most important income stream for many poor countries. There is an urgent need to ensure social cohesion and solidarity through policies that protect and support the most vulnerable groups when jobs disappear and deepen inequalities.

Managing the effects of the pandemic forces us to start a real debate on how to best implement a policy response to reach all segments of the population. To a large extent, economic policy will determine the ability of society to cope with the emergency and its consequences.

Politics comes into play by igniting the debate on policies in response to a universal threat. This does not come as a surprise; almost all economists believe that small countries would be better off if they removed all trade barriers. However, unilateral free trade is something practically unusual, and no country in the world promotes it today. It is difficult for governments to apply the right economic policies, precisely because politics and economy do not find common strategies, and thus politics finds the usual answers, and perhaps it is politics that prevents governments from better-applying policies, even in the face of imminent crises, failing in finding the right solutions to develop the right economic policies.

Politics strikes the economy and the economy strikes in politics, forcing governments to relaunch the economy mainly in the function of the acquisition and maintenance of power, and therefore often in the function of the elections, generating the so-called high and low political and economic cycles of economic activity, just at the time of the elections. The economic situation has a strong impact on elections. Politicians have revealed the simple fact that economic growth rates and inflation are the criteria for predicting the results fairly accurately, for example for the presidential elections in the United States. This is often not the case, as politicians often do not choose the best policies.

In short, the political economy is the integration of political and economic factors into our analysis of modern society. Politics and economics are closely and irremediably intertwined: politics affects the economy and economics influence politics - this approach should be natural. All of this shows that to be effective it is necessary to understand governments and societies at a time of profound change. Leaders should take these important factors into account when addressing the Covid19 pandemic.

A crisis of this magnitude is a global turning point, leading economists and other analysts to broaden their imaginations and experiment with radical new ideas about how the world works. We can say that it is a reinvention of the world, where ideas that have not worked in a world too committed to the profit of the capitalist system could find space. We could finally find the time to take care of the environment, to look at a greener, smarter, more technologically intelligent, fairer, and more compassionate world. Perhaps this will be an opportunity to rethink the fundamentals of our social and economic life.

The economic issue seems to prevail over both health and politics. COVID-19 therefore seems to pose a huge threat to health and economic prosperity in the world. On the other hand, having unleashed volatility in financial markets and anger at the slow or insufficient responses of governments, the virus has also highlighted the lack of confidence in our institutions, especially those in Europe, caught unprepared and perhaps even inadequate.

Before the pandemic crisis, many countries had solid economic performances, practically at the level of full employment. One would have expected that the main institutions of society such as governments, companies, media, communication, and organizations would manage to govern the crisis shows that, on a global scale, 
people do not trust institutions and the institutions do what they have to do. Unfortunately, the paradox is how to trust dynamics have evolved over the past 20 years and how financial markets depend on investor confidence, less on politics, and less on economic rules. COVID-19 impacted, and it was a big shock, which is why at this extraordinarily difficult time, institutions must go beyond expectations and restore confidence in investors, in people.

Governments are now challenged to demonstrate their competence in dealing with the crisis. The media must act as objective referees of the facts. Companies must offer the necessary products and supplies. The information must be reliable. Eventually, the ball will return to politics. Politicians may see with some fear the possible consolidation of public finances after the pandemic crisis, but given the budget decisions they will have to make, it will lead them to consider the "exceptional situation". However, fiscal consolidation through tax reforms will not have a high political cost, economic and political issues will always have to be considered together.

Crises can never be predicted. The states of the world have adopted such different models of action in the face of the pandemic. Alas, our loneliness also becomes instructive in terms of leisure, work, and consumption.

\section{Conclusion}

Recent data on health and economy show a strong alteration of the pandemic and consequently an evolution of the economy that suggests, as the European Commission claims, a recovery in 2021 much weaker than expected; the rapid spread of the virus has surprised everyone, politicians, and economists. At this point, it is necessary to be aware that we are facing a transition in which it will be difficult to keep the emergency and transformation of the world separate. In this new context, it is necessary to avoid essential emergency interventions, represent a moment of the chase of events, instead of their prevention.

The choices in the health and economy sector must be structured in such a way that the emergency is linked to a medium-term program that is essential to ensure the exit from recession to pursue viable strategies.

As we know, pandemics, economic crises, and climate instability, which is an issue that remains to be addressed and which only aggravates the global crisis, will have repercussions. The importance today must be given to resilience, which we understand as the ability of society to absorb change and adapt to it and prevent systemic failure (Betrus, 2020). The same importance must then be given to efficiency today.

Complex systems present multidimensional interactions between people, sectors, institutions, and policies; interactions with a wide variety of feedback cycles, interdependent trajectories, delays between cause and effect, and turning points, in this case, we need to look beyond, set new horizons.

Looking into the past is important but this world looks different; it is rapidly changing thanks to technology. This is changing the nature of economies and in parallel human interaction.

The power of traditional rulers is changing; it passes to good institutions able to manage reliably the change of the world order. After all, the pandemic follows the mutations due to storms, heat waves, floods, and droughts that warn us that with their periodic devastation traditional climate models are also in crisis. Moreover, there are social unrest and inequality, everything is set in a context of uncertainty and we ask ourselves the question of where will the work come from in the future or how the social contract will be.

In this world, there is no way to predict the exact consequences of systemic fragility. Institutions and decision-making processes presuppose a degree of predictability. The pandemic and environmental crisis suggest how we must act and what basic principles can guide us in the transition to a new political economy.

In all corners of the world, ways are being tested to apply new principles, think of the design of products in a "circular economy" that eliminates waste or networks with multiple participants focused on systemic transformation. The pandemic and its consequences should stimulate the expansion of these experiments to obtain the right resilience value that our global and at the same time very complex society needs, which, however, should also be based on the analysis of human nature.

The decision to look immediately at the needs arising from the resurgence of the COVID-19 can go well provided that a macroeconomic compatibility framework and a "vision" for development are immediately defined. Here the policy must interact taking into account the health issue. This pandemic is not something that alarms the world in the short term. Other similar events can be repeated in the future, as today the world 
has become one unit.

Each state must necessarily proceed to an allocation of resources taking into account pandemic events that cannot be considered only as emergency interventions, to these are added the allocations for growth and development programs that, on the contrary, are not always defined (Bresnahan, Trajtenberg, 1995).

And yet history does teach. In 1918, as it is today, it was immediately understood that gatherings were a source of contagion, but a pandemic ends when there is no uncontrolled transmission of the community and cases are at a very low level. Then, when the effects subsided, people stopped worrying. After the Spanish flu and the First World War, the roaring 1920s arrived and so the population that managed to survive entered a phase of euphoria in every sense, including economic euphoria, but even in this phase of post-influenza optimism, totalitarian regimes began to emerge in the fertile ground of border control, individualism and the desire for autarchy, hopefully, this history will not repeat itself. Today the world has focused on internationalization, the economic system is based on finance and less on industry and agriculture, and it must rediscover the philosophy of mankind.

Investing in human capital is essential for today's world and, even more so, for the world of the future; this gives us a glimpse of the extent to which the enemy is often not the coronavirus, but ourselves.

Ultimately, pandemics like this require not only science but also prudence (MacKenzie, 2020). This means, among other things, recognizing that no science can solve our idea of politics and society, or our idea of death, or the way we educate young people and treat the elderly, or exhaust our idea of death, virtue, and education, but also a simple idea, sometimes mythical and even metaphysical, around which philosophical, political and religious problems of enormous importance revolve.

If at the end we will learn a lesson from the Covid-19 pandemic, it is that the end of the health crisis is a necessary condition for achieving lasting economic recovery, and this will only be possible if targeted interventions are in place to protect the most vulnerable groups. The pandemic is and will be related to a new recession, but today we cannot predict its exact extent even though there is every reason to predict that this recession will be much deeper and longer than in 2008. This crisis affects businesses and employment all over the world, but it will bring profound social and political changes, and prevent the crisis from leading to a lasting increase in unemployment the economic and political measures to be taken must be rapid so as not to aggravate inequality. In any case we are witing the vaccine (Mosley, 2020), solution for all? If this is not done, the distance between rich and poor will increase, and history teaches us the prospect of conflict. We cannot take the risk.sm

\section{References}

Angeletti L.R., \& Gazzaniga V. (2008). Storia, filosofia ed etica generale della medicina. Milano: Elsevier Masson.

Betrus, M. (2020), Covid-19: Lockdowns on Trial, Jennifer. Madison: Blanchard editors.

Bresnahan, T., \& Trajtenberg, M. (1995). General purpose technologies: Engines of Growth? Journal of Econometrics, 65 (1), 83-108. https://doi.org/10.1016/0304-4076(94)01598-T

Chauncey Crandall M.D. (2020). Fight back, West Palm Beach, FL: Humanix Books.

Figus A. (2020). Coronavirus COVID - 19, a complex issue between health, economy, politics, and communication, Geopolitical, Social Security and Freedom Journal, 1, $1-14$. https://doi.org/10.2478/gssfi-2020-0001

Kelly, J. (2020). In 1918, Americans were asked to wear masks. Some refused - and paid the price. Retrieved December 1, 2020, from

https://www.washingtonpost.com/local/in-1918americans-were-asked-to-wear-masks-some-refused-and-paid-the-price/2020/07/01/748d3fde-bbb5-11ea80b9-40ece9a701dc_story.html

LePan, N. (2020). Visualizing the History of Pandemics. Retrieved December 1, 2020, from

https://www.washingtonpost.com/local/in-1918americans-were-asked-to-wear-masks-some-refused-and-paid-the-price/2020/07/01/748d3fde-bbb5-11ea80b9-40ece9a701dc_story.html

Lopez F. (2004). II pensiero olistico di Ippocrate. Percorsi di ragionamento e testimonianze, Vol. I, Cosenza: Edizioni Pubblisfera.

MacKenzie D. (2020). Covid-19: The Pandemic that Never Should Have Happened and How to Stop the Next One, London: Little, Brown Book Group Limited.

Mosley M. (2020). Covid-19: Everything You Need to Know about the Corona Virus and the Race for the Vaccine. London: Short Books.

Treccani Dictionary. (2020). Dizionario Medicina.

United Nations Conference on Trade and Development, (2020). COVID-19 drives large international trade declines in 2020. Retrieved December 1, 2020, from https://unctad.org/statistics

United Nations (2020). COVID-19: nuovo rapporto sulla situazione dell'OMS, Retrieved December 1, 2020, from https://unric.org/it/covid-19-nuovo-rapporto-sullasituazione-delloms-2

World Health Organization. (2020). WHO Coronavirus Disease (COVID-19) Dashboard. Retrieved December 1, 2020, from https://covid19.who.int/ 


\section{$\triangle$ Correspondence}

\section{Alessandro Figus}

University of Cassino and Southern Lazio, Italy Loc. Folcara, 03043, Cassino, Fr, Italy

E-mail: alessandro.figus@unicas.it 